ORIGINAL ARTICLE

\title{
Urine mutagenicity and lymphocyte DNA damage in fruit growers occupationally exposed to the fungicide captan
}

\author{
P Lebailly, A Devaux, D Pottier, M De Meo, V Andre, I Baldi, F Severin, J Bernaud, B Durand, \\ M Henry-Amar, P Gauduchon
}

Occup Environ Med 2003;60:910-917

See end of article for authors' affiliations ......................

Correspondence to: Dr P Lebailly, Registre Général des Tumeurs du Calvados, Centre François Baclesse, Route de Lionsur-Mer, 14076 Caen Cedex 5, France; lebailly@baclesse.fr

Accepted 11 January 2003

\begin{abstract}
Aims: To determine haematological parameters, urine mutagenicity (on three Salmonella typhimurium strains), and DNA damage (using the comet assay) in mononuclear leucocytes of farmers before and after a one-day spraying period of pear and apple trees with the fungicide captan in usual conditions.

Methods: Fruit growers were exposed to captan during the $1998(n=12)$ and/or the 2000 spraying seasons $(n=17)$. Biological samples were collected on the morning of the day of spraying $(S 1)$, the evening after spraying (S2), and the morning of the day after (S3). The UK Predictive Operator Exposure Model (UK-POEM) was used to quantify pesticide exposure intensity.

Results: No effect was observed on haematological parameters for these two spraying seasons. Proportions of mutagenic urine samples did not significantly differ between S1 and S2/S3 sampling points. In contrast with strains TA97a and YG1041 mainly sensitive to frameshift mutations, a positive trend was observed between the difference (S3-S1) of mutagenic power on strain TA102 detecting basepair mutations and the exposure predicted value given by UK-POEM, mainly due to parameters related to protective clothing. No significant variations in DNA damage levels were observed between S1 and S3, nor were correlations observed with parameters of pesticide exposure.

Conclusions: A one-day spraying period with captan and other pesticides does not significantly induce DNA damages in mononuclear leucocytes. In contrast, an inefficient protective clothing could correlate with an increase in urine mutagenicity as assessed by the TA102 tester strain.
\end{abstract}

$\mathrm{P}$ esticides form a heterogeneous group of chemicals that may play a role in cancer aetiology. A relation between occupational exposure to pesticides and risk of developing malignant tumours, including leukaemia and nonHodgkin's lymphoma, has been suggested by epidemiological studies, ${ }^{1}$ but remains to be firmly established. ${ }^{2}$ In order to further elucidate the carcinogenic risk associated with pesticide exposure, most studies focused on genomic modifications assessed by sister chromatid exchanges, chromosomal aberrations, and/or micronuclei in lymphocytes of people occupationally exposed to pesticides. Results have been conflicting, ${ }^{3}$ and may at least in part reflect the heterogeneity of pesticide exposure (for example, levels of exposure can vary considerably; and pesticides are used in various farming activities such as fruit growing, flower or fruit cultivation in greenhouses, or open field farming). Most studies were cross-sectional with comparisons between groups of people for whom only one sample per individual was collected. In contrast, repeated blood sample collection applied to the same individual before and after one period of heavy pesticide exposure with quantitative assessment of pesticide exposure was used in a limited number of studies.

Occupational exposure to pesticides among farmers is complex and consists of a sequence of spraying days with one or several pesticides sprayed each day. To give some insight into the biological plausibility of the role of pesticides in cancer risk among farmers, we collected blood and urine samples very close to exposure periods to selected pesticides widely used in open field farming, in orchards, or in vineyards. Biomarkers of short term genotoxicity, such as the salmonella mutagenicity assay ${ }^{4}$ and DNA damage assessed by the alkaline comet assay ${ }^{5}$ can be used to monitor exposure. These assays have rarely been used on people occupationally exposed to pesticides, ${ }^{6-9}$ and all concluded that occupational exposure to pesticides is associated with a clear, ${ }^{78}$ sometimes limited, ${ }^{69}$ genotoxic effect.

Captan is the most frequently used fungicide on apple and pear trees in many countries. This pesticide has been classified as potentially carcinogenic to humans by the European Community; it belongs to group 3 of the International Agency for Research on Cancer (IARC) classification (that is, sufficient evidence to establish the mutagenicity of captan in cellular systems, but insufficient data to establish its mutagenicity in mammals). ${ }^{10}$

The aim of our study was to assess the effects of a one-day spraying period with captan on haematological parameters, urine mutagenicity, and DNA damage in 19 fruit growers for a total of 29 application days.

\section{MATERIALS AND METHODS \\ Subjects}

Selected individuals were identified through a local fruit grower organisation and lived in a single geographical area (département du Rhône) mainly devoted to orchards and vineyards $(52 \%$ of farms). These subjects were enrolled because they currently used the fungicide captan on apple or pear trees. Informed consent was obtained from each subject prior to the beginning of the study. Information on individual characteristics (age, health status, and medical history) and lifestyle (diet, smoking habits including passive smoking exposure, alcohol, and medication) were collected as recommended, ${ }^{11}{ }^{12}$ using a face to face questionnaire completed at the farmer's home a few weeks/days prior to blood withdrawal and urine collection. Data on occupational exposure related to agricultural activities (pesticides used in crop treatment, chemicals used in cattle care, welding, mechanical repairs, etc) were collected at the S1 sampling point; details 


\section{Main messages}

- A one-day spraying period with captan and other pesticides does not significantly induce DNA damage in mononuclear leucocytes.

- Inefficient protective clothing could correlate with an increase in urine mutagenicity as assessed by the TA102 tester strain.

of the characteristics of pesticide exposure during the oneday spraying period of concern (doses, sprayed areas, type of engine and crop sprayer, protective clothes during mixingloading and spraying, commercial formulations used, etc) were collected at home at the time of the second blood collection (S3).

Three spot urines were collected using one-litre urine containers. For each individual, the first sample was collected on the morning of the day of spraying (sample S1). The second one included all the evening's urine voids (sample S2). A third sample was collected on the morning of the day after captan exposure (sample S3). Urine samples were stored at $-20^{\circ} \mathrm{C}$ until extraction. Venous blood samples were collected at home by nurses using heparinised (comet assay) and EDTA (haematological parameters) treated vacutainer tubes at times corresponding to S1 and S3. Blood samples were collected at rest, at the same time schedule to rule out circadian variations. Maximum and minimum blood pressures as well as heart rate were measured in order to take into account physical activity which can induce DNA damage detectable with the alkaline comet assay. ${ }^{13}$

The study was conducted over two spraying seasons. Blood and urine samples were collected in 19 male fruit growers, of whom 10 participated for the two spraying seasons: years 1998 and 2000. Two farmers participated for the 1998 spraying season and seven farmers for the 2000 spraying season.

\section{Pesticide exposure assessment}

The United Kingdom Predictive Operator Exposure Model (UK-POEM) was used to calculate the predicted absorbed dose of captan. ${ }^{14}$ This model was developed by a panel of experts from data obtained after external pesticide exposure measurements under various agricultural activities. The predicted absorbed dose of pesticide is the sum of three components reflecting the absorbed dose from: (1) dermal exposure during mixing-loading tasks (DEML); (2) dermal exposure during application tasks (DEA); and (3) respiratory exposure during application tasks (REA). It is expressed in $\mathrm{mg}$ of pesticide per day.

DEML, DEA, and REA include variables that depend on the physical nature of the formulation (solid or liquid), the design and size of the product pack, the number of individual containers that have been handled, and the design of the sprayer being used. According to this model, dermal contamination, during mixing-loading tasks with a wettable powder (which is the formulation of captan used in this study) is estimated to be $100 \mathrm{mg}$ for each bag of more than $1 \mathrm{~kg}$. Estimated contamination during application is fixed to $400 \mathrm{ml}$ and to $0.02 \mathrm{ml}$ of diluted spray per hour of spraying for the dermal and respiratory routes, respectively. The fixed contamination is modulated by a number of variables for each step of pesticide use. For captan (wettable powder) on orchards, the following equations were used:

$\mathrm{DEML}=100 \mathrm{mg} / \mathrm{bag} \times \mathrm{NHS} \times \mathrm{VCC} / \mathrm{VP} \times \mathrm{CAI} \times \mathrm{PC} \times \mathrm{DA}$

\section{Policy implications}

- Assessment of occupational exposure needs to be improved and parameters predictive of intensity of exposure need to be validated.

where:

NHS is the number of hectares sprayed

VCC is the number of $\mathrm{kg}$ of commercial product used per ha

VP is the weight of each bag (in $\mathrm{kg}$ )

CAI is the concentration of the active ingredient in the

formulation in $\mathrm{mg} / \mathrm{g}$ (here $830 \mathrm{mg} / \mathrm{g}$ )

PC equals 0.01 if rubber gloves are worn and 1 otherwise DA is the dermal absorption fixed to 0.1 .

$$
\begin{aligned}
\mathrm{DEA}= & (400 \mathrm{ml} / \mathrm{h} \times \mathrm{NH} \times \mathrm{VCC} \times \mathrm{CAI} \times \mathrm{VWH}) \times \\
& (\mathrm{EH}+\mathrm{EL}+\mathrm{ET}) \times \mathrm{DA}
\end{aligned}
$$

where:

$\mathrm{NH}$ is the number of hours of spraying

VWH is the number of litres of water per ha

$\mathrm{EH}$ is the exposure of the hands that depends on of the use of rubber gloves $(=0.01)$ or not $(=0.025)$

EL is the exposure of legs that depends on the use of

protective clothes $(=0)$ or normal clothes $(=0.013)$

ET is the exposure of the trunk that depends on the use of protective clothes $(=0)$ or normal clothes $(=0.0125)$.

$$
\mathrm{REA}=0.02 \mathrm{ml} / \mathrm{h} \times \mathrm{NH} \times \mathrm{VCC} \times \mathrm{CAI} / \mathrm{VWH}
$$

\section{Cells}

From peripheral blood samples, mononuclear cells were Ficoll separated and cryopreserved in liquid nitrogen without stimulation according to a previously described procedure. ${ }^{15}$

\section{Haematological parameters}

Platelets, white cells (neutrophils, lymphocytes, monocytes, eosinophil and basophil granulocytes), and red cells counts were obtained using an automated counter S+(Coultronix).

\section{Urine mutagenicity analysis}

Eighty seven frozen urine samples were thawed at room temperature and filtered through a Whatman (No. 1) filter. A small volume was reserved for creatinine measurement by the Jaffé reaction, using a Cobas Mira+ device. Urine extraction was performed on pre-packed Bakerbond-speSDB-1 columns (Mallinckrodt Baker Laboratories, Noisy le Sec, France). Resins were first conditioned with $2 \times 5 \mathrm{ml}$ of methanol followed by $2 \times 5 \mathrm{ml}$ Milli-Q water. Urine samples were passed through the columns using a vacuum manifold system. Resins were then rinsed with $10 \mathrm{ml}$ Milli-Q water. This procedure eliminated traces of water soluble growth factors (especially histidine) from the resins. Residual water was removed by vacuum aspiration. Adsorbed substances were eluted with $10 \mathrm{ml}$ of methanol/acetonitrile v/v. After evaporation to dryness with a SpeedVac system, residue was dissolved in dimethylsulphoxide to reach a 500-fold concentration factor. Once prepared, urine extracts were kept in liquid nitrogen until use. All urine samples but one were subsequently concentrated. The microincubation procedure of the salmonella mutagenicity assay has been described by De Méo and colleagues. ${ }^{4}$ Mutagenicity was evaluated in overnight cultures of Salmonella typhimurium tester strains TA102 and TA97a without S9mix and YG1041 with S9mix. Each colony forming unit came from the growth of one bacterial cell that reverted its original mutation in the 
histidine locus and was called revertant and noted His+. Mean spontaneous backgrounds of induced revertants are indicated in table 4; the day to day variability was low. S9mix was prepared with 5\% of Aroclor-1254 induced S9 as previously described. ${ }^{16}$ Experiments using triplicate plates per dose were performed and included a blank (dimethylsulphoxide) and four concentrations of urine extract, corresponding to $2,3,4$, and $5 \mathrm{ml}$ of urine. For each set of experiments, positive control for each strain and S9mix were also included. These controls included ICR 191 ( $0.4 \mathrm{ng} / \mathrm{plate})$ for strain TA97a, mitomycine C (0.4 ng/plate), and benzo[a]pyrene $(0.5 \mu \mathrm{g} /$ plate $)$ for quality control of S9mix. After 48 hours of incubation, the revertants were counted on each plate with a laser colony counter equipped with a bacterial enumeration program (Spiral System Instruments Inc., Bethesda, MD, USA).

\section{DNA damage assessment using the alkaline comet assay}

Immediately before comet assay, cryopreserved mononuclear leucocytes were rapidly thawed. Total cell count and cell viability, expressed as the percentage of living cells, were evaluated using the trypan blue exclusion method. Negative controls (mononuclear leucocytes from one healthy man without known exposure to genotoxic agents) were processed together with farmers' samples. The comet assay was processed under minimal illumination at room temperature according to a procedure previously described..$^{15}$ Cells were suspended in 200-300 $\mu \mathrm{l}$ prewarmed low melting point agarose $(0.5 \%$ in phosphate buffered saline) and put on a microscope slide precoated with normal agarose $(0.8 \%$ in phosphate buffered saline). A third layer of $0.5 \%$ low melting point agarose was added. Slides were then put in a tank filled with a freshly made lysis solution $(2.5 \mathrm{M}$ $\mathrm{NaCl}, 0.1 \mathrm{M}$ EDTA, $10 \mathrm{mM}$ Tris adjusted to $\mathrm{pH} 10,10 \%$ dimethylsulphoxide, and $1 \%$ Triton X-100 both freshly added) for at least one hour. To allow DNA unwinding, slides were incubated in a freshly made electrophoresis buffer $(0.3 \mathrm{M} \mathrm{NaOH}$ and $1 \mathrm{mM}$ EDTA, $\mathrm{pH}>13)$ for $40 \mathrm{~min}$ utes. Slides were then placed in an horizontal electrophoresis tank (Hoeffer HE $99 \mathrm{X}$ ), immersed in fresh electrophoresis buffer, and exposed to 0.7 volts/cm for 24 minutes (300 mA). After electrophoresis, slides were washed twice in freshly made neutralisation buffer $(0.4 \mathrm{M}$ Tris adjusted to $\mathrm{pH} 7.5$ with concentrated hydrochloric acid). Slides were stained with $50 \mu \mathrm{l}$ ethidium bromide solution $(20 \mu \mathrm{g} / \mathrm{ml})$, covered with a coverslip, and observed at $250 \times$ magnification using a Dialux fluorescence microscope (Leitz) equipped with a Ploemopak 2.3 (excitation filter: 515-560 nm; barrier filter: $580 \mathrm{~nm})$.

For each experiment, 14 slides were processed together, including samples of mononuclear leucocytes from three farmers and a negative control (RPMI medium without fetal calf serum). The two samples ( $\mathrm{S} 1$ and S3 time points), collected from each farmer were tested in duplicate in the same assay and at least two independent experiments were made by two investigators ( $\mathrm{AD}$ and PL).

For each slide, 100 randomly selected cells ( 50 cells by each of the two investigators) were submitted to image analysis (Kinetics Imaging, Komet version 3.1 or an original software Aphelion comet pro 4.0). Tail moment was used to express results and was defined as the product of the percentage of DNA in the tail and the displacement between the head and tail mean centres. For highly damaged cells (HDC) (fig 1, panel D), the tail moment could not be easily calculated, and if not, was fixed to 75 . When calculated, the HDC tail moment always approached this value.

\section{Viability and basal DNA damage in negative} controls

Cell viability immediately after lymphocyte isolation was always above $98 \%$. Immediately after thawing, viability of human lymphocytes was above $90 \%$. After thawing, overall $10-25 \%$ of cells presented with DNA damage (damaged or highly damaged) in negative controls; the level of DNA damage did not significantly differ between experiments.

\section{Statistical analysis}

For haematological parameter changes, the difference between S1 and S3 was tested to null using the paired Student's $t$ test.

Results obtained with the Ames assay were analysed using two statistical tests in order to: (1) determine a dose-effect relation between the volume of urine extract and the number of His+ colonies using the models proposed by Kim and Margolin; ${ }^{17}$ and (2) detect a significant increase (mutagenic effect) or decrease (toxic effect) of at least one of the four doses of urine tested against the spontaneous background of His+ colonies. This analysis was made using the Dunnett test. Briefly, Kim and Margolin ${ }^{17}$ proposed a software (SALM) that performs regression analyses using one linear and two nonlinear models. ${ }^{17}$ These arbitrary models tend to design typical dose-response curves that are obtained from pure chemicals. The two non-linear models include two parts: a doseresponse increase, not necessarily linear; and a dose-response decrease related to toxicity. A sample was considered to be mutagenic when at least one of these two statistical tests provided a $\mathrm{p}$ value smaller than 0.05 . The mutagenic power was then calculated as the difference between the highest number of His+ colonies at a given dose of urine extract and the spontaneous background of the corresponding experiment; it was expressed as the net number of revertants per mmol creatinine. The mutagenic power was fixed to null if none of the statistical tests described above were significant or if a significant toxic effect was detected (that is, number of His+ colonies smaller than the spontaneous background).

Parametric and non-parametric statistical tests were used for results obtained with the comet assay. The parametric paired Student's $t$ test was performed after exclusion of HDC. In results expressed using arithmetic means, changes in the proportion of HDC greatly modified the mean and could mask other DNA damage level modifications. Furthermore, distributions of DNA damage were not Gaussian. Finally, HDC might represent necrotic and/or apoptotic cells. ${ }^{18-20}$ The non-parametric Wilcoxon test was also used to compare changes in tail moment distributions between S1 and S3.

The relation between pesticide exposure and biological parameters was estimated using the $\chi^{2}$ test or the Fisher exact test, as appropriate, or using a Spearman nonparametric regression model. The STATA statistical software (STATA Corporation, release 5.0), the SALM software, StatXact 4 for Windows (Cytel Software Corporation, 1998), and SAS release 6.12 software (SAS Institute, 1990) were used.

\section{RESULTS}

Overall, 19 farmers participated and provided biological samples for at least one of two spraying seasons. Urine and blood samples were collected for 12 farmers in the 1998 spraying season and for 17 during the 2000 spraying season. Viable lymphocytes, allowing for DNA damage assessment using the comet assay, were only available from the 1998 spraying season (12 S1 and $12 \mathrm{~S} 3$ blood samples); a total of 87 urine samples were collected (29 subjects with urine samples S1, S2, and S3).

All fruit growers were males, average age 39 years (range 22-53) for the 1998 spraying season and 40 years (range 

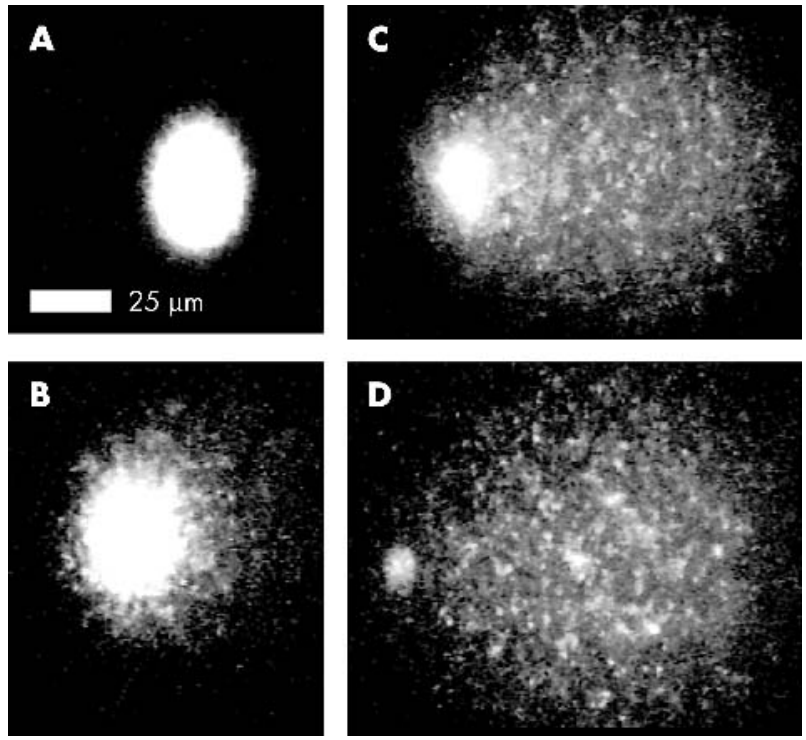

Figure 1 Digitised comet images of individual leucocytes with various degrees of DNA damage: (A) undamaged cell (tail moment $<1$ ); (B) slightly damaged cell (tail moment 1-5); (C) damaged cell or classical comet (tail moment $>5$ ); (D) highly damaged cell (HDC, tail moment $\sim 75)$.

20-55) for the 2000 spraying season. Two were current smokers (daily tobacco consumption of 8 or 13 cigarettes). Daily alcohol consumption, assessed using a semi-quantitative approach, was similar in the two spraying season groups. Forty two per cent of farmers reported no alcohol consumption, $31 \%$ drank alcohol once a day with a meal (1998: 33\% and 2000: 29\%), and the remaining 27\% drank alcohol for at least two meals per day (25\% and 29\%). Three farmers were under regular medication, including antihistamine, antihypertensive, or anti-inflammatory drugs (table 1).

The mean total farm area of farmers having participated in the 1998 spraying season was 17 ha (range 6-26 ha); it was 16 ha (range 6-37 ha) for those of the 2000 spraying season. Fifty four per cent of the total farm area was devoted to fruit growing (range 14-91\%); this proportion did not differ between the two spraying seasons. Tables 2 and 3 summarise exposure characteristics. Forty five percent $(n=13)$ of application days were with pesticide use the day before exposure to captan and the remainder were with pesticide use two to six days before. The pesticides used the day before S1 belonged to fungicides (7/13 of application days, half of them with phtalimides) and/or insecticides (9/13 application days, six of them with organophosphorus); two application days were with herbicides. Concerning pesticide exposure characteristics between S1 and S2/S3, captan was mixed ( $83 \%$ of the application days) with other pesticides on pear or apple trees and/or other pesticides were used when other crops were treated these days. Up to five other pesticides, mainly fungicides and/or insecticides, were used with captan (1.8 on average). Among fungicides, triazoles (14\% of application days) and diazines $(24 \%)$ were the most often used. Among insecticides, carbamates were used for nine application days (31\%) and ureas for seven application days $(24 \%)$. The amount of other pesticides used was on average $14 \%$ of that of captan (range $1-60 \%$ ) and for $60 \%$ of farmers using other pesticides, it was less than $10 \%$ of the amount of captan. Moreover, $82 \%$ of the area (3.3 ha in average) sprayed the day of the study were sprayed with captan. On average, $1.8 \mathrm{~kg}$ of wettable powder captan (range 1.0-2.3) was applied per ha of apple or pear trees leading to a mean total quantity of captan used per day of $4.9 \mathrm{~kg}$ (range 1.3-10.8). Fourteen per cent $(n=4)$ of the 29 days of mixing-loading of captan were without any protective clothing, $14 \%(n=4)$ with mask or protective clothes, $17 \%(\mathrm{n}=5)$ with rubber gloves only, $14 \%(\mathrm{n}=4)$ with rubber gloves and mask or protective clothes, and $41 \%(n=12)$ with all protective clothing (rubber gloves + mask + protective clothes). Twenty four per cent $(\mathrm{n}=7)$ of application days were without protective clothing, $14 \%(n=4)$ with protective clothes and/or mask, $14 \%(n=4)$ with rubber gloves with protective clothes or mask, and $48 \%$ $(n=14)$ with all protective devices. Only four $(14 \%)$ days of spraying activities were achieved with tractors equipped with an isolation cabin.

Using the UK-POEM, the mean predicted dose of absorbed captan was $14.8 \mathrm{mg}$ (range 1.2-66.1) for the 1998 spraying season and $14.0 \mathrm{mg}$ (range 0.9-45.3) for the 2000 spraying season (table 2). The mean body mass of fruit growers was $74 \mathrm{~kg}$ (range 59-85). The acceptable daily intake (ADI) for long term captan exposure in Europe is $0.01 \mathrm{mg} / \mathrm{kg} / \mathrm{day}$. Based on the predicted absorbed dose of captan calculated using the UK-POEM, all fruit growers presented with value above the ADI for chronic exposure with an average value of 19 times this ADI $0.19 \mathrm{mg} / \mathrm{kg} /$ day (range 1.06 to 82.6). No significant difference in heart rate and blood pressure were observed between S1 and S3. None of the haematological parameters significantly changed between the two blood sampling points except for a $20 \%$ significant $(p<0.05)$ decrease in the number of basophils. No correlations were observed between haematological changes and pesticide exposure parameters (data not shown). Three farmers, however, had higher than normal values of eosinophils and two of them noted seasonal allergies.

Urine mutagenicity was evaluated on three Salmonella typhimurium strains: TA102 and TA97a without S9mix and YG1041 with addition of S9mix at three time points (S1, before exposure, compared to S2 and S3, after exposure). Table 4 indicates mean spontaneous frequencies of revertants. The day to day variability was low. Overall, $6 \%$ of urine samples (5/86) were mutagenic on TA97a without S9mix, $20 \%(17 / 86)$ on TA102 without S9mix, and 59\% (50/85) on YG1041+S9mix. Even if the proportion of mutagenic urine samples was high at S1 for YGl041 (56\%), none of the parameters related to confounding factors (medication, consumption of broiled meat the day before S1, smoking excepted) or to the type of work the day before S1 (pesticide exposure including pesticide spraying, re-entry tasks like pruning, tractor and sprayer maintenance, welding) were associated with that proportion or with the mutagenic power of urine samples (data not shown). Similarly, no relation was observed between the proportion of mutagenic samples or the mutagenic power on tester strains TA97a or TA102 and pesticide exposure the day before S1 (type of pesticides sprayed, area sprayed, etc). The mean mutagenic power on the TA102 tester strain at S3 for urine defined as mutagenic was 1602 net revertants $/ \mathrm{mmol}$ creatinine (table 4). A statistically significant $(p<0.01$ linear regression, $p=0.03$, Spearman's $\rho_{\mathrm{o}}=0.40$ ) positive correlation was observed between the predicted absorbed dose of captan and the mutagenic power of urine samples calculated for TA102 at S3 (fig $2 \mathrm{~A}$ ) but not at $\mathrm{S} 2$. Such a relation $(\mathrm{p}<0.05)$ was also found when the mutagenicity was quantified by the induced ratio (see table 4 ).

Three of the five fruit growers with a UK-POEM value exceeding $30 \mathrm{mg}$ presented with significant urine mutagenicity at S3 on the TA102 strain versus only two (9\%) of the 23 fruit growers with UK-POEM values below $30 \mathrm{mg}$ (fig 2A). The five fruit growers with mutagenic urines on TAl02 at S3 did not differ from the remaining 24 for other variables collected in the questionnaire (type of pesticides handled 
Table 1 Individual and lifestyle characteristics of the 19 fruit growers at enrolment in the study*

\begin{tabular}{|c|c|c|c|c|c|}
\hline $\begin{array}{l}\text { Mean age (SD) } \\
\text { [range] }\end{array}$ & Smoking habits & & Drinking hab & & Medication \\
\hline $38(9)$ [20-53] & $\begin{array}{l}\text { Current smokers } \\
\text { Ex-smokers } \\
\text { Never smokers }\end{array}$ & $\begin{array}{r}2(10 \%) \\
6(32 \%) \\
11(58 \%)\end{array}$ & $\begin{array}{l}\text { Unusual } \\
\text { Once a day } \\
\text { More }\end{array}$ & $\begin{array}{l}42 \% \\
31 \% \\
27 \%\end{array}$ & Regular $3(16 \%) \dagger$ \\
\hline
\end{tabular}

*19 fruit growers for 29 different application days.

†Antihistamine, antihypertensive, or anti-inflammatory drugs

with captan, medication, etc). No statistically significant differences in proportions of mutagenic urines were observed according to the sampling points whatever the salmonella strain. For the three strains, the mutagenic power of urine samples was not statistically different between S1 and S2 or S3. A positive correlation $(\mathrm{p}=0.07$ linear regression analysis, Spearman's $\rho_{\mathrm{o}}=0.56, \mathrm{p}=0.002$ ) was observed between the difference (S3-S1) of the mutagenic power of urine samples on the TA102 tester strain and the predicted absorbed dose of captan (fig 2B). This relation could be a consequence of protective clothing. It was the only parameter among those used in the UK-POEM to calculate the predicted ingested dose of captan (see methods section) to individually correlate with the variation of mutagenic power on the TA102 tester strain. An almost significant negative correlation (Spearman's $\rho_{\mathrm{o}}=0.37, \mathrm{p}=0.051$ ) was observed between the protective clothing during mixing-loading tasks (see table 2) and the variation of the mutagenic power on tester strain TA102. A similar observation was observed with protective clothing during application tasks. In addition, the reproducibility of observed association (correlation with UKPOEM values and with protective clothing) for the second spraying season was also examined and a similar trend observed (data not shown).

Lymphocyte DNA damage was measured for 12 farmers at two sampling points (table 4 ). Overall, $10 \%$ of lymphocytes were classified as damaged or highly damaged cells at S1 and $13 \%$ at S3. This level of DNA damage was lower or close to those measured on negative controls for almost $70 \%$ of the samples. No relations were observed between confounding factors (alcohol or fruit beverage consumption, medication) and level of DNA damage observed at S1 (data not shown). No statistically significant variations of DNA damage were observed between S1 and S3. Three of the 12 farmers, however, showed a significant $(\mathrm{p}<0.01$, paired Student's

Table 2 Pesticide exposure characteristics for the day of captan use

\begin{tabular}{lcc}
\hline & Mean (SD) & Range \\
\hline Quantity of captan used (kg) & $4.9(2.4)$ & $1.3-10.8$ \\
Area sprayed (ha) & $3.3(1.8)$ & $1.2-8.9$ \\
Time of spraying (h) & $3.5(1.9)$ & $1.0-8.5$ \\
UK-POEM values (mg captan) & $14.4(16.0)$ & $0.9-66.1$ \\
\hline & Mixing- & \\
Protective clothes & loading & Application \\
\hline Without rubber gloves* & $8(28 \%)$ & $11(38 \%)$ \\
With rubber gloves & $9(31 \%)$ & $4(14 \%)$ \\
With all personal protective devices $\neq$ & $12(41 \%)$ & $14(48 \%)$ \\
\hline
\end{tabular}

*Including farmers without any protective devices 4 for mixing and 7 for application), with protective clothes alone (1 for mixing and 1 for application), with mask alone (3 for mixing and 1 for application). with mask and protective clothes (2 for application).

†Jointly with mask (1 for mixing and 3 for application), or with protective clothes (3 for mixing and 1 for application).

flncluding farmers with all 3 protective devices (rubber gloves, protective clothes, and mask). $t$ test) increase in their mean level of DNA damage at S3; two others exhibited only a significant $(\mathrm{p}<0.05$, Wilcoxon test) increase in DNA damage level, and one a significant $(\mathrm{p}<0.001$, Wilcoxon test $)$ decrease. No correlations were observed between various pesticide exposure parameters (table 2) and the variation of DNA damage level between S1 and S3 (data not shown).

\section{DISCUSSION}

Captan has been shown to be genotoxic in numerous short term assays in vitro. ${ }^{21} 22$ Captan is able to interact with DNA, especially to form DNA adducts and DNA-protein crosslinks ${ }^{23}$ and more specifically inducing mutation through base-pair substitution mechanisms including those detected by TA102 or TA104 Salmonella typhimurium strains. ${ }^{24}{ }^{25}$ Recent studies have confirmed the ability of captan to be highly mutagenic on strains detecting base-pair mutations, ${ }^{26}{ }^{27}$ and not on strains sensitive to frameshift mutations such as
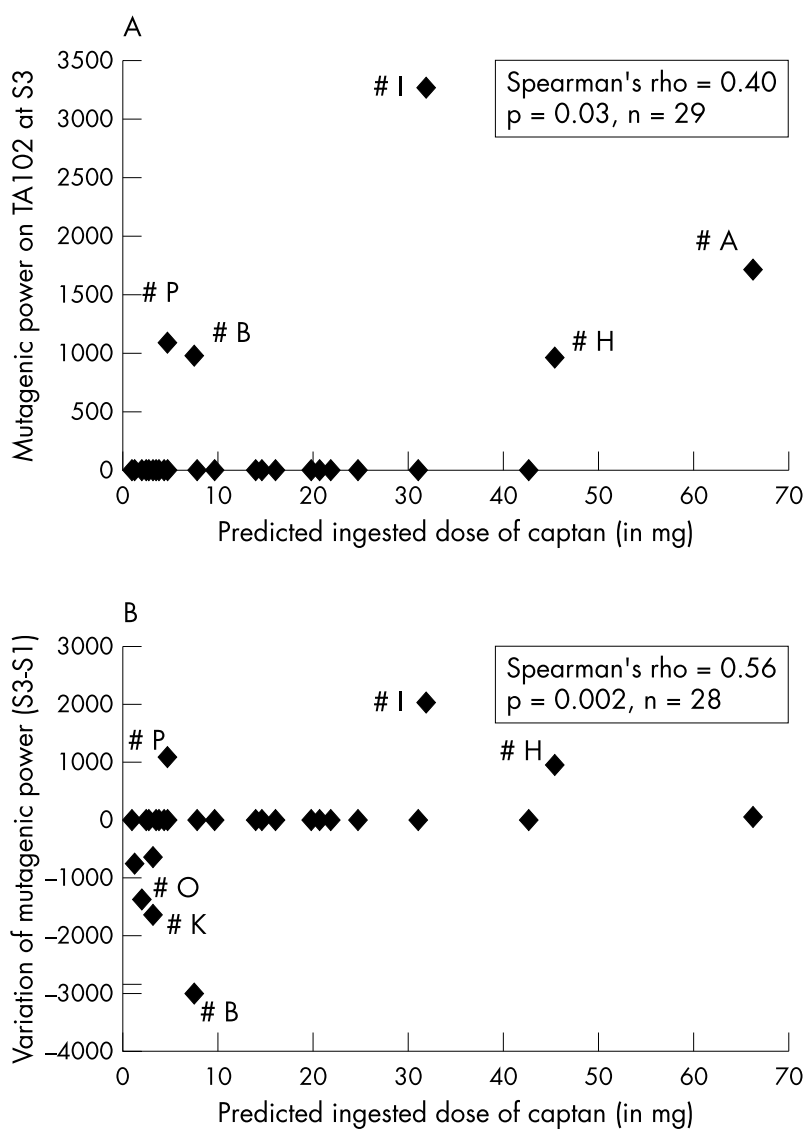

Figure 2 Relations between the UK-POEM predicted value of ingested captan and (A) the mutagenic power detected on TA102 without S9 at $\mathrm{S} 3$, or (B) the difference in the mutagenic power between S3 and S1. \#, identification of the farmers. 
Table 3 Pesticides used the day before sampling and the day of captan use

\begin{tabular}{|c|c|c|}
\hline \multirow[b]{2}{*}{ Pesticide } & \multicolumn{2}{|c|}{ Number of users (\%) } \\
\hline & $\begin{array}{l}\text { The day before } \\
\text { S1 ( } n=13,45 \%)\end{array}$ & $\begin{array}{l}\text { Between S1 } \\
\text { and S3 }\end{array}$ \\
\hline \multicolumn{3}{|l|}{ Fungicides } \\
\hline Phtalimides & $3(10 \%)$ & $29(100 \%)$ \\
\hline Captan & $1(3 \%)$ & $29(100 \%)$ \\
\hline Folpet or iprodione & $2(7 \%)$ & $2(7 \%)$ \\
\hline $\begin{array}{l}\text { Carbamates (thiophanatemethyl, } \\
\text { benomy)) }\end{array}$ & $2(7 \%)$ & $1(3 \%)$ \\
\hline $\begin{array}{l}\text { Triazoles (flusilazol, triadimefon, } \\
\text { penconazol, myclobutanil) }\end{array}$ & $1(3 \%)$ & $4(14 \%)$ \\
\hline Phenols (dinocap) & - & $3(10 \%)$ \\
\hline $\begin{array}{l}\text { Diazines (buripimate, } \\
\text { chinomethionate, pyrazophos) }\end{array}$ & $1(3 \%)$ & $7(24 \%)$ \\
\hline Thiadiazine (dazomet) & - & $1(3 \%)$ \\
\hline Pyridine (pyrifenox) & $1(3 \%)$ & $3(10 \%)$ \\
\hline Sulphamide (tolylfluanide) & - & $1(3 \%)$ \\
\hline Oxyquinoleate & $1(3 \%)$ & - \\
\hline \multicolumn{3}{|l|}{ Insecticides } \\
\hline Organochlorine (endosulfan) & $2(7 \%)$ & $2(7 \%)$ \\
\hline $\begin{array}{l}\text { Carbamates (fenoxycarb, } \\
\text { pyrimicarb, carbaryl) }\end{array}$ & $1(3 \%)$ & $9(31 \%)$ \\
\hline Ureas (teflubenzuron, flufenoxuron) & - & $7(24 \%)$ \\
\hline $\begin{array}{l}\text { Organophosphorus (phosalon, } \\
\text { dimethoate, methidathion, } \\
\text { vamidothion) }\end{array}$ & $6(21 \%)$ & $3(10 \%)$ \\
\hline Avermectin (abamectin) & - & $1(3 \%)$ \\
\hline Chloronicotinil (imidaclopride) & $2(7 \%)$ & $2(7 \%)$ \\
\hline - Formamidin (amitraz) & - & $1(3 \%)$ \\
\hline \multicolumn{3}{|l|}{ Herbicides } \\
\hline Simazine, diuron, or glyphosate & $2(7 \%)$ & $1(3 \%)$ \\
\hline
\end{tabular}

TA98. ${ }^{27}$ Results from in vivo studies are even more dissimilar. Captan was not able to induce chromosomal aberration in the mouse. ${ }^{22}$ In an in vivo carcinogenicity bioassay, borderline results were obtained with captan on the induction of preneoplastic lesions in rat liver. ${ }^{28}$ Difficulties in studying in vivo captan genotoxicity might relate to its high cytotoxicity through mechanisms such as lipid peroxidation. ${ }^{29}$ Finally, captan belongs to IARC classification group $\mathrm{III}^{10}$ and to EPA classification group B2. ${ }^{30}$

In the present study, urine mutagenicity (on three Salmonella typhimurium strains) and DNA damage (using the comet assay) in mononuclear leucocytes of farmers were measured before and after a one-day spraying period with captan on orchards in usual conditions. The analysis of the impact of pesticide exposure onto the biomarkers above was not only based on a comparison between before spraying (S1) and after spraying (S2 or S3) time points but also on the assessment of correlations between changes in biomarker levels and captan exposure related parameters. Moreover, the study was conducted for two different spraying seasons in order to assess the reproducibility of the observation. Urine mutagenicity and DNA damage measured by the comet assay on lymphocytes are suitable biomarkers in population studies when biological effects are examined shortly after exposure. As shown among fruit growers exposed to captan, urinary excretion of THPI, the main metabolite of captan, has been shown to reach its maximum level the day after exposure. ${ }^{31}$ Similarly, clastogenic activity in urine extracts obtained from fruit growers was detected within eight hours after pesticide application. ${ }^{32}$ These results suggest that time points for urine collections in the evening of the day of exposure (S2) and in the morning of the day after exposure (S3) are appropriate.

The protocol was designed to be the most sensitive for the detection of a mutagenic effect with the Ames assay, which led us to use an adsorbent appropriate to pesticide residues ${ }^{33}$ and a 500-fold concentration factor of urine. Moreover, the decision to confirm a mutagenic effect was mostly (79\% of the 72 urines classified as mutagenic) based on the presence of a dose-response effect detected by the Kim and Margolin method.

Parameters used to quantify occupational exposure to pesticides in fields have most often been the area sprayed and/or the time spent in spraying (number of hours per day and/or number of days per year). Several studies have shown, at least for fruit growing, ${ }^{31}$ that other parameters could be of particular interest, such as the amount of pesticides handled and the type of spraying equipment. In a study conducted in the Netherlands on external dermal exposure in fruit growers applying captan on apple trees, the mean quantity of captan used in the observed days of exposure was $3.7 \mathrm{~kg}$ (range 0.3$10)$, which was very similar to that observed in our study. De Cock et al measured levels of cutaneous contamination ranging from 0.47 to $48.6 \mathrm{mg} / \mathrm{h} / \mathrm{m}^{2}$, depending on pad location and type of spraying equipment. ${ }^{34}$

Few models are currently available to simultaneously consider a set of quantitative (amount handled, duration of exposure, etc) as well as qualitative (protection used) exposure parameters. The UK-POEM is among those used for registration purposes in European countries. To our knowledge, it has not been used in studies focusing on genotoxic biomarkers. Based on the predicted absorbed dose of captan calculated with the UK-POEM, all fruit growers included in this study presented with a 19-fold increased exposure value on average (range 1.06-82.6) above the European acceptable daily intake $(0.01 \mathrm{mg} / \mathrm{kg} / \mathrm{day})$. It would probably be more accurate to compare the UK-POEM calculated value to the acceptable operator exposure level (AOEL) derived from data issued from mutagenicity/carcinogenicity assays because only few days per year are devoted to captan spraying activities. However, these data are not presently available. Similarly, captan was the sole pesticide used on only $17 \%$ of the application days; on the remaining days up to five other pesticides were used. However, the amount of these pesticides represented only $14 \%$ of that of captan. Such a situation is usual in agricultural activities, especially in fruit growing, but also in open field farming. ${ }^{7}$ Our selection was targeted on captan because there was some evidence of its genotoxicity and it was one of the most used pesticides on orchards.

In our study, other pesticides were used the day before S1 in $45 \%$ of application days. These pesticides were almost identical to those used between S1 and S2/S3 (table 3). No relations were observed between biological parameters and pesticide used the day before S1. Since we did not observe any significant increases in urine mutagenicity or DNA damage after a one-day use of captan and other pesticides, we have no reason to believe that similar pesticides (captan excepted) will induce a genotoxic effect detectable at S1 and not at S2 or S3.

Our results show that the increase in the urine mutagenic power measured with strain TA102 correlated with the UK-POEM predicted value of absorbed captan. Moreover, this correlation was noted for the two spraying seasons. The correlation between UK-POEM values and urine mutagenicity on the TA102 strain could be a consequence of the influence of parameters related to protective clothing. These parameters are the only ones among all parameters included in the UK-POEM to correlate individually with the increase of the mutagenic power of urine samples.

In another study ${ }^{9}$ among non-smoking farmers with open field farming activities, the frequencies of mutagenic urine samples were 19\% (7/37) on TA97a without S9mix and 25\% (9/36) on TA102 without S9mix. In that study, no correlation 
Table 4 Results of urine mutagenicity using three salmonella tester strains and of DNA damage in lymphocytes

\begin{tabular}{|c|c|c|c|c|}
\hline Genotoxicity assay & Parameters & $\mathrm{S1}{ }^{*}$ & $S 2^{*}$ & $\mathrm{~S} 3^{*}$ \\
\hline $\begin{array}{l}\text { Salmonella mutagenicity assay } \\
\text { Salmonella strain YG1041 with } \\
\text { S9mix }[M S B \dagger=143(16)]\end{array}$ & $\begin{array}{l}\text { Mean ratio ( SD) } \ddagger \\
\text { [range] } \\
\text { Number of mutagenic urines (\%) } \\
\text { Mean mutagenic power§ } \\
\text { [range] }\end{array}$ & $\begin{array}{l}1.29(0.17) \\
{[1.03-1.69]} \\
15 / 27(56 \%) \\
1854(1262) \\
{[485-5216]}\end{array}$ & $\begin{array}{l}1.42(0.46) \\
{[1.07-3.55]} \\
18 / 29(62 \%) \\
2675(2470) \\
{[538-9623]}\end{array}$ & $\begin{array}{l}1.34(0.26) \\
{[0.95-2.10]} \\
17 / 29(59 \%) \\
2261(2038) \\
{[583-7107]}\end{array}$ \\
\hline $\begin{array}{l}\text { Salmonella strain TA97 without } \\
\text { S9mix [MSB } \dagger=164(15)]\end{array}$ & $\begin{array}{l}\text { Mean ratio (SD) } \ddagger \\
\text { [range] } \\
\text { Number of mutagenic urines (\%) } \\
\text { Mutagenic power }\end{array}$ & $\begin{array}{l}1.04(0.11) \\
{[0.84-1.30]} \\
2 / 28(7 \%) \\
398 \& 2409\end{array}$ & $\begin{array}{l}1.09(0.10) \\
{[0.90-1.27]} \\
2 / 29(7 \%) \\
480 \& 1932\end{array}$ & $\begin{array}{l}1.07(0.11) \\
{[0.82-1.40]} \\
1 / 29(3 \%) \\
3209\end{array}$ \\
\hline $\begin{array}{l}\text { Salmonella strain TA102 without } \\
\text { S9mix }[\mathrm{MSB}+=337(31)]\end{array}$ & $\begin{array}{l}\text { Mean ratio (SD) } \ddagger \\
\text { [range] } \\
\text { Number of mutagenic urines (\%) } \\
\text { Mean mutagenic power§ } \\
\text { [range] }\end{array}$ & $\begin{array}{l}1.11(0.10) \\
{[0.91-1.37]} \\
7 / 28(25 \%) \\
1612(1128) \\
{[650-4005]}\end{array}$ & $\begin{array}{l}1.08(0.09) \\
{[0.93-1.23]} \\
5 / 29(17 \%) \\
1465(1067) \\
{[701-3321]}\end{array}$ & $\begin{array}{l}1.07(0.10) \\
{[0.80-1.25]} \\
5 / 29(17 \%) \\
1602(980) \\
{[966-3266]}\end{array}$ \\
\hline \multicolumn{5}{|l|}{ Alkaline comet assay } \\
\hline & $\begin{array}{l}\text { Mean \% DNA damage } \\
\text { [range] } \\
\text { Mean tail moment w/o HDC** (SD) } \\
\text { [range] }\end{array}$ & $\begin{array}{l}10 \% \\
{[2-21 \%]} \\
4.35(1.11) \\
{[2.16-5.85]}\end{array}$ & $\begin{array}{l}\text { NT+† } \\
\text { NT }\end{array}$ & $\begin{array}{l}13 \% \\
{[5-49 \%]} \\
4.80(2.57) \\
{[3.18-12.76]}\end{array}$ \\
\hline \multicolumn{5}{|c|}{$\begin{array}{l}\text { *Time points for biological sampling: S1, the morning the day of captan use; S2, the evening the same day; and S3, the morning the day after. } \\
\text { tMSB, mean spontaneous background (SD) between individual experiments. } \\
\text { tRatio between the highest number of reverse mutations in urine samples and the spontaneous background of the corresponding experiment. } \\
\text { SMutagenic power calculated as the net His+ colonies/mmol urine creatinine for urines classified as mutagenic according to statistical analysis. } \\
\text { 'Percentage of nuclei ranked as damaged or highly damaged. } \\
\text { **HDC, highly damaged cell. } \\
\text { t†NT, not tested. }\end{array}$} \\
\hline
\end{tabular}

was observed between pesticide exposure and modifications of urine mutagenicity. The mutagenic frequencies calculated for the two strains were similar to those determined among fruit growers in the present study $(6 \%$ and $20 \%$ for TA97 and TA102, respectively).

Although smoking is the major confounding factor in the evaluation of the mutagenic activity of urine samples using the Ames assay, other factors, such as alcohol consumption and medication, may play a role. ${ }^{35}$ In our study, a smoking effect was detectable on the YG104l tester strain with the metabolic fraction only. The two smokers were among those presenting with the highest induced number of revertants. YG1041 is the resulting strain of Salmonella typhimurium TA98 in which the plasmid carrying both acetyltransferase and nitroreductase genes was introduced. YG104l expresses high levels of these enzymes and becomes much more sensitive to the mutagenic action of nitro-aromatic compounds and aromatic amines. $^{36}$

One remaining question concerns the high prevalence of mutagenic urine samples on YG104l strain without any correlation with data issued from the questionnaire (medication, roasted food, mechanical repairs, and welding). At least two hypotheses can be pointed out to explain this lack of correlation: (1) the effect of factors present in the food and/or related to agricultural activities such as diesel exhaust or other factors not accurately considered in the questionnaire; and (2) a lack of specificity (large number of false positives) of the method when positivity is assessed by the Kim and Margolin model, which was developed for in vitro studies with higher expected differences in the number of colonies between tested doses.

Similarly to conventional cytogenetic methods, the alkaline comet assay (a rapid, simple, and sensitive method to detect various types of DNA damages) provides information at the single cell level although it is not limited to proliferating cells. Increasing number of studies use this assay for assessment of the genotoxic effect of occupational exposure. ${ }^{37}$

The percentages of damaged cells did not vary between the two sampling time points (10\% versus $13 \%$, for S1 and S3, respectively). These percentages were somewhat smaller than those measured previously in 41 farmers with open-field farming activities (16\%, 14\%, and $22 \%$ at the beginning, middle, and end of the spraying season, respectively) even after exclusion of current smokers. ${ }^{7}$ This higher level of DNA damage among open-field farmers could be a consequence of exposure characteristics such as the type of pesticides used or the lack of protective clothing in almost all farmers included in the study. Observed differences in DNA damage level between open-field farmers and fruit growers could also be due to other individual factors such as differences in food consumption.

Among confounding factors that could modulate DNA damage in healthy individuals, smoking ${ }^{13}$ and exhaustive physical activity ${ }^{38}$ could be ruled out in this study because none of the farmers were smokers in the 1998 spraying season, and subjects were their own controls, with blood sampling taken at rest on the mornings before and after pesticide exposure. Other studies have shown that highly damaged cells, also called hedgehog cells, represent necrotic ${ }^{20}$ and/or apoptotic cells. ${ }^{18}{ }^{19}$ Excluding these cells from the analysis did not modify the results.

In conclusion, the lack of correlation between classical parameters of pesticide exposure and DNA damage level or urine mutagenicity can stem from three reasons: (1) a lack of genotoxic effect of captan in vivo in humans, at least at this level of exposure; (2) the existence of a genotoxic effect that would not modify the results of the tests used (that is, no genotoxic compound excreted in urine and no clastogenic compound present at a sufficient level in the blood); or (3) the used parameters are not accurate for estimating pesticide exposure. The positive correlation found between an integrated pesticide exposure parameter (UK-POEM value) and the mutagenic power onto the TAl02 strain should be considered with caution even if it strengthens the need to increase the knowledge of parameters that should be used in the quantitative assessment of occupational exposure to pesticides. Studies are currently ongoing to assess the level of 
leucocyte DNA adducts in blood samples taken from the same population using the ${ }^{32} \mathrm{P}$ post-labelling method.

\section{ACKNOWLEDGEMENTS}

We are indebted to Misses Bardou and Brouet for interviews with farmers, nurses who collected blood samples in the home, and Coopérative agricole SICOLY (in particular Mr Massardier) for the enrolment of farmers. Pierre Lebailly was recipient of a fellowship from the Ligue Nationale Contre le Cancer (Comité de la Manche) which also granted this work (Comités de la Manche et du Rhône), as well as the Union des Industries pour la Protection des Plantes, the Association pour la Recherche sur le Cancer, and the Conseil Général du Calvados.

\section{Authors' affiliations}

P Lebailly, D Pottier, V Andre, M Henry-Amar, P Gauduchon, GRECAN (EA-1772), Université de Caen, 14076 CAEN Cedex 5, France A Devaux, Laboratoire des Sciences de l'Environnement, Vaulx en Velin, and INRA, Département Hydrobiologie et Faune Sauvages, Rennes, France

M De Meo, Laboratoire de Biogénotoxicologie et Mutagenèse Environnementale (EA 1784), Faculté de Pharmacie, Université de la Méditerranée, Marseille, France

I Baldi, Laboratoire Santé Travail Environnement, Bordeaux, France F Severin, Association de Coordination Technique Agricole, Lyon, France

J Bernaud, Etablissement Français du Sang de Lyon, France

B Durand, Hôpital de la Croix Rousse, Laboratoire d'Hématologie, Lyon, France

\section{REFERENCES}

1 Blair A, Malker H, Cantor KP, et al. Cancer among farmers. A review. Scand'J Work Environ Health' 1985;11:397-407.

2 Acquavella J, Olsen $G$, Cole $P$, et al. Cancer among farmers: a meta-analysis. Ann Epidemiol 1998;8:64-74.

3 Maroni M, Fait A. Health effects in man from long-term exposure to pesticides. A review of the 1975-1991 literature. Toxicology 1993;78:105-12.

4 De Méo M, Laget M, Di Giorgio C, et al. Optimization of the salmonella/ mammalian microsome assay for urine mutagenesis by experimental designs. Mutat Res 1996;340:51-65.

5 Rojas E, Lopez MC, Valverde M. Single cell gel electrophoresis assay: methodology and applications. J Chromatogr B Biomed Sci Appl 1999;722:225-54.

6 Shane BS, Scarlett-Kranz JM, Shaw Reid W, et al. Mutagenicity of urine from greenhouse workers. J Toxicol Environ Health 1988;24:429-37.

7 Lebailly P, Vigreux C, Lechevrel C, et al. DNA damage in mononuclear leukocytes of farmers measured using the alkaline comet assay: modifications of DNA damage levels after a one-day field spraying period with selected pesticides. Cancer Epidemiol Biomarkers Prev 1998;7:929-40.

8 Garaj-Vrhovac V, Zeliezic D. Cytogenetic monitoring of Croatian population occupationally exposed to a complex mixture of pesticides. Toxicology 2001;165:153-62.

9 Andre V, Lebailly P, Pottier D, et al. Urine mutagenicity of farmers occupationally exposed during a one-day use of chlorothalonil and insecticides. Int Arch Occup Environ Health 2003;76:55-62.

10 World Health Organisation (France). International Agency for Research on Cancer monographs on the evaluation of the carcinogenic risk of chemicals to humans, No. 30. Lyon: 1983

11 Carrano AV, Natarajan AT. International Commission for Protection against Environmental Mutagens and Carcinogens: ICPEMC Publication no. 14 Considerations for population monitoring using cytogenetic techniques. Mutat Res 1988;204:379-406

12 Albertini RJ, Anderson D, Douglas GR, et al. IPCS guidelines for the monitoring of genotoxic effects of carcinogens in humans. International Programme on Chemical Safety. Mutat Res 2000;463:111-72.

13 Moller P, Knudsen LE, Loft S, et al. The comet assay as a rapid test in biomonitoring occupational exposure to DNA-damaging agents and effect of confounding factors. Cancer Epidemiol Biomarkers Prev 2000;9:1005-15

14 Joint Medical Panel of the Scientific Subcommittee on Pesticides and the British Agrochemical Association (UK). Estimation of exposure and absorption of pesticides by spray operators. Harpenden: Ministry of Agriculture, Food and Fisheries, 1986.

15 Lebailly P, Vigreux C, Lechevrel C, et al. DNA damage in mononuclear leukocytes of farmers measured using the alkaline comet assay: discussion of critical parameters and evaluation of seasonal variations in relation to pesticide exposure. Cancer Epidemiol Biomarkers Prev 1998;7:917-27.

16 Maron DM, Ames BN. Revised methods for the salmonella mutagenicity test. Mutat Res 1983;113:173-215.

17 Kim BS, Margolin BH. Statistical methods for the Ames salmonella assay: a review. Mutat Res 1999;436:113-22.

18 Olive PL, Banath JP. Sizing highly fragmented DNA in individual apoptotic cells using the comet assay and a DBA crosslinking agent. Exp Cell Res 1995:221:19-26.

19 Godard T, Deslandes E, Lebailly P, et al. Early detection of staurosporineinduced apoptosis by comet and annexin $\mathrm{V}$ assays. Histochem Cell Biol 1999;1 12:155-61.

20 Hartmann A, Kiskinis E, Fjallman A, et al. Influence of cytotoxicity and compound precipitation on test results in the alkaline comet assay. Mutat Res 2001;497:199-212.

21 Tezuka H, Ando N, Suzuki R, et al. Sister-chromatid exchanges and chromosomal aberrations in cultured Chinese hamster cells treated with pesticides positive in microbial reversion assays. Mutat Res 1980;78:177-91.

22 Garrett NE, Stack HF, Waters MD. Evaluation of the genetic activity profiles of 65 pesticides. Mutat Res 1986;168:301-25.

23 Snyder RD. Effects of captan on DNA and DNA metabolic processes in human diploid fibroblasts. Environ Mol Mutagen 1992;20:127-33.

24 Bridges BA. The mutagenicity of captan and related fungicides. Mutat Res 1975:32:3-34.

25 Barrueco $\mathrm{C}$ de la PE. Mutagenic evaluation of the pesticides captan, folpet captafol, dichlofluanid and related compounds with the mutants TA102 and TA104 of Salmonella typhimurium. Mutagenesis 1988;3:467-80.

26 Ruiz MJ, Marzin D. Genotoxicity of six pesticides by salmonella mutagenicity test and SOS chromotest. Mutat Res 1997:390:245-55.

27 Hour TC, Chen L, Lin JK. Comparative investigation on the mutagenicities of organophosphate, phthalimide, pyrethroid and carbamate insecticides by the Ames and lactam tests. Mutagenesis 1998;13:157-66.

28 Cabral $R$, Hoshiya $T$, Hakoi $K$, et al. A rapid in vivo bioassay for the carcinogenicity of pesticides. Tumori 1991;77:185-8.

29 Suzuki T, Komatsu M, Isono H. Cytotoxicity of organochlorine pesticides and lipid peroxidation in isolated rat hepatocytes. Biol Pharm Bull 1997;20:271-4.

30 Quest JA, Fenner-Crisp PA, Burnam W, et al. Evaluation of the carcinogenic potential of pesticides. 4. Chloroalkylthiodicarboximide compounds with fungicidal activity. Regul Toxicol Pharmacol 1993;17:19-34.

31 De Cock J, Heederik D, Hoek F, et al. Urinary excretion of tetrahydrophtalimide in fruit growers with dermal exposure to captan. Am J Ind Med 1995;28:245-56.

32 See RH, Dunn BP, San RH. Clastogenic activity in urine of workers occupationally exposed to pesticides. Mutat Res 1990:241:251-9.

33 Pichon V, Cau dit Coumes C, Chen L, et al. Simple removal of humic and fulvic acid interferences using polymeric sorbents for the simultaneous solid-phase extraction of polar acidic, neutral and basic pesticides. J Chromatogr $A$ 1996:737:25-33.

34 De Cock J, Heederik D, Kromhout H, et al. Determinants of exposure to captan in fruit growing. Am Ind Hyg Assoc J 1998;59:166-72.

35 Mure K, Takeshita T, Takeuchi T, et al. Urinary mutagens and lifestyle factors. Prev Med 1996;25:569-74.

36 Hagiwara $Y$, Watanabe $M$, Oda $Y$, et al. Specificity and sensitivity of Salmonella typhimurium YG1041 and YG1042 strains possessing elevated levels of both nitroreductase and acetyltransferase activity. Mutat Res 1993;291:171-80.

37 Sram RJ, Binkova B. Molecular epidemiology studies on occupational and environmental exposure to mutagens and carcinogens, 1997-1999. Environ Health Perspect 2000; 108(suppl 1):57-70.

38 Hartmann A, Plappert U, Raddatz K, et al. Does physical activity induce DNA damage? Mutagenesis 1994:9:269-72.

39 Tsai K, Hsu TG, Hsu KM, et al. Oxidative DNA damage in human peripheral leukocytes induced by massive aerobic exercise. Free Radic Biol Med 2001;31:1465-72. 